Pupa.-Length, $9 \mathrm{~mm}$. Colour bright green with two white stripes on the dorsum, extending from the head to the tip of the abdomen.

Cocoon.-Very thin, loose and white.

\title{
NOTES ON THE LIFE HISTORY OF ARGYRIA NIVALIS, DRURY
}

BY E. PORTER FELT, B. S., FORT PLAIN, N. Y.

This moth was rather common at Ithaca, New York, in I 892 and 1893 . The moths fly in the afternoon and early evening of the latter part of June and most of July. They are attracted to lights to some extent, but those taken are mostly males. The eggs are laid in clusters upon blades of grass. They are firmly attached to the leaf, and the five or six in a cluster over-lap more or less.

The eggs hatch in ten or twelve days. The young larvæ were placed in a cage containing grass, clover and considerable moss. They soon disappeared, and subsequent observation proved they had constructed cylindrical nests in the moss. The nests were composed of bits of moss and were smoothly lined with silk. Some of the nests were perpendicular, others were horizontal. The larvæ devoured all the moss before any perceptible amount of grass was eaten. After the grass was eaten they began on the clover, and soon not a green thing was left in the cage.

When about a month old the larvæ are $2 . \mathrm{cm}$. long, and their nests are three to four centimetres long. At this time the nests are mostly above the surface of the ground. There seem to be no indications of more than one generation a year. They probably hibernate in their nests as larvæ, and in the spring complete the round of life much as do some species of Crambus. $E_{g s}$-Yellowish-white, flattened, oval, r.2 mm. by $.87 \mathrm{~mm}$. Shell finely reticulated. (Fig. 8.)

Larva, first stage. - Head diameter, $.33 \mathrm{~mm}$. ; body diameter, $.27 \mathrm{~mm}$; length, I.65 mm. Head and thoracic shield jet black. Body a straw colour with a broad transverse carmine stripe on the fifth and seventh segments. Spots of the same colour occur on the eleventh and twelfth segments, and also just above each pair of legs. Five pairs of prolegs, occurring on the seventh Fig. 9- Egg and micro- to tenth and thirteenth segments inclusive.
pyle. Greatly enlarged. 